be subducted again - yet that is what is implied by these widely separated ages of eclogite formation in a single sample.

The work by Herwartz and colleagues ${ }^{3}$ provides a fascinating glimpse into the history of one enigmatic sheet of rock in the Alps. At the same time, it raises the question of whether there is a systematic process by which the edges of continents can be subducted repeatedly into the mantle during the closure of one or more ocean basins ${ }^{4}$.
Hannes Brueckner is at Queens College, City University of New York, Flushing, New York 11367, USA and at Lamont-Doherty Earth Observatory, Columbia University, Palisades, New York 10964-8000, USA.

e-mail:hannes@ldeo.columbia.edu

\section{References \\ 1. Chemenda, A. I., Mattauer, M. \& Bokun, A. N. \\ Earth Planet. Sci. Lett. 143, 173-182 (1996).}

2. Ernst, W. G. Terra Nova 17, 165-188 (2005).
3. Herwartz, D., Nagel, T. J., Münker, C., Scherer E. E. \& Froitzheim, N. Nature Geosci. 4, 178-183 (2011).

4. Brueckner, H. K. in Metamorphic Conditions Along Convergent Plate Junctions: Mineralogy, Petrology, Geochemistry and Tectonics (eds Ernst, W. G. \& Rumble, D.) 80-97 (International Book Series of the Geological Society of America Vol. 10, Bellwether, 2008).

5. Franke, W. in Orogenic Processes: Quantification and Modeling in the Variscan Belt (eds Franke, W., Hakk, V., Oncken, O. \& Tanner, D.) 35-61 (Geological Society Special Publication 179, 2000).

Published online: 23 January 2011

\title{
WILLI DANSGAARD
}

\section{From isotopes to ice}

Without the deep ice cores from Greenland and Antarctica, the climatic and environmental changes over the past 800,000 years would be much less precisely documented. The key tools for reconstructing continuous palaeotemperature records are measurements of the oxygen and hydrogen isotope ratios in ice, even though they are now complemented by other methods. Willi Dansgaard, who died on 8 January 2011 at the age of 88 , spear-headed the use of the stable isotopes of water in climatology and palaeoclimatology, especially as applied to deep ice cores.

This scientific adventure started in 1952. On 21 June, Willi Dansgaard collected rain samples as a low-pressure system was passing over Denmark. He was intrigued by their isotopic composition and decided to investigate. Eventually, he showed that isotopic values of warm-front rain reflect the formation temperature in the cloud.

Over the next 12 years, he systematically collected and analysed water samples from all over the world. In 1964, these data and their interpretation were published in a seminal article 'Stable isotopes in precipitation' (Tellus 16, 436-468; 1964). Most important was the confirmation that, for mid- and high-latitude sites, the colder the climate, the lower the isotopic values. This observation is the founding principle of climate reconstruction from measuring water isotopes in ice cores.

Already in the 1950s, Willi Dansgaard wanted to study old ice. However, the technique of ice-core drilling had not yet been developed. So he started with analysing ice from marginal glaciers and from icebergs. His subsequent work benefited from drilling activity led by the US Cold Regions and Engineering

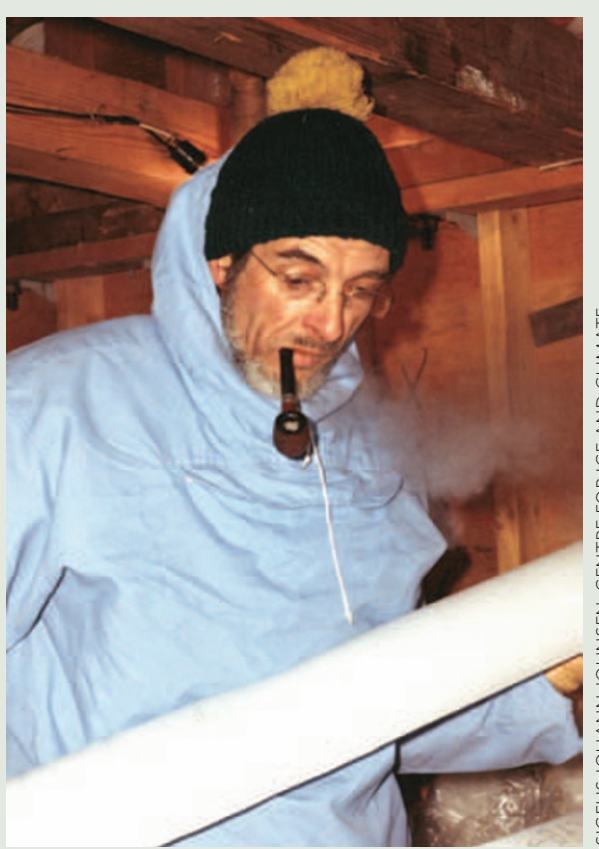

hope of launching a joint US-European drilling project in central Greenland. It was a surprise to all when Dansgaard, disappointed by the difficulties in getting the collaboration with the US off the ground, told the meeting we should go for two cores, instead of a joint project. The decision is history: two cores were drilled $30 \mathrm{~km}$ apart, GRIP and GISP2. In hindsight, the information gained by comparing the records provided by these two cores proved invaluable. I also distinctly remember Willi's excitement at the GRIP bedrock party on 12 July 1992. The success of this European drill project was the crowning achievement in the career of a scientist who is today recognized as the founder of modern icecore climate research.

When he retired that same year, Willi Dansgaard had built a strong research group, including a team dedicated to drilling technology. His style of leadership was marked by his hot temper, his very short patience with what he called 'details', and his strong focus on the scientific goals. He was great at including everybody, senior as well as very junior, in important decisions and created a strong team spirit. Members of his group will remember his dedication and determination, always towards progress of science.

Willi Dansgaard's legacy survives in the Centre for Ice and Climate in Copenhagen, which has been very active in the large European ice-drilling projects in Antarctica and has led international projects in Greenland such as NGRIP and NEEM.

\section{JEAN JOUZEL}

Jean Jouzel is at the Institut Pierre Simon Laplace/Laboratoire des Sciences du Climat et de l'Environnement, CEA-CNRS-UVSQ, 91191

Gif sur Yvette, France.

e-mail: jean.jouzel@lsce.ipsl.fr 